\begin{tabular}{|c|c|}
\hline 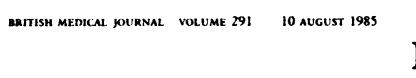 & PRACTICE OBSERVED \\
\hline \multicolumn{2}{|l|}{ Practice Research } \\
\hline \multicolumn{2}{|c|}{$\begin{array}{l}\text { Polymyalgia rheumatica/giant cell arteritis in a Cambridge } \\
\text { general practice }\end{array}$} \\
\hline V KYLE, B SILVERMAN, A SILMAN, H KI & NG, N OSWALD, B REISS, B HAZLEMAN \\
\hline 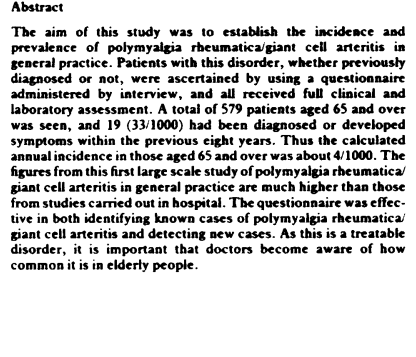 & 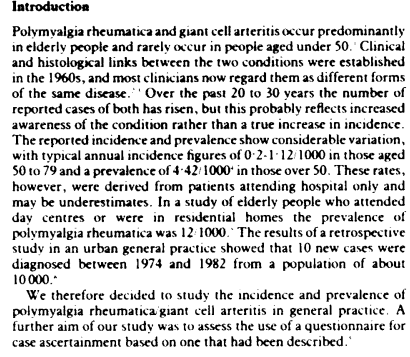 \\
\hline 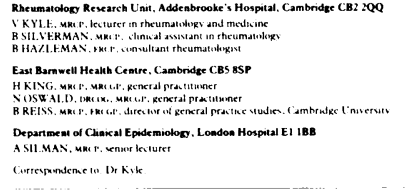 & 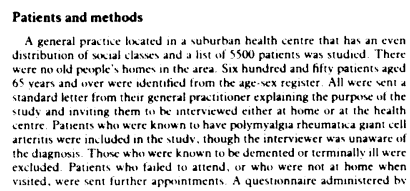 \\
\hline
\end{tabular}

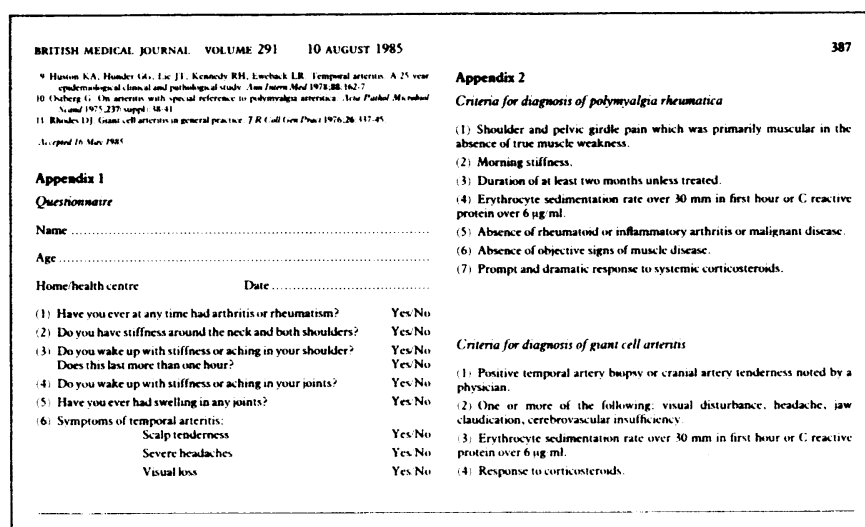

\title{
Ear wax and otitis media in children
}

ANNE FAIREY, C B FREER, D MACHIN
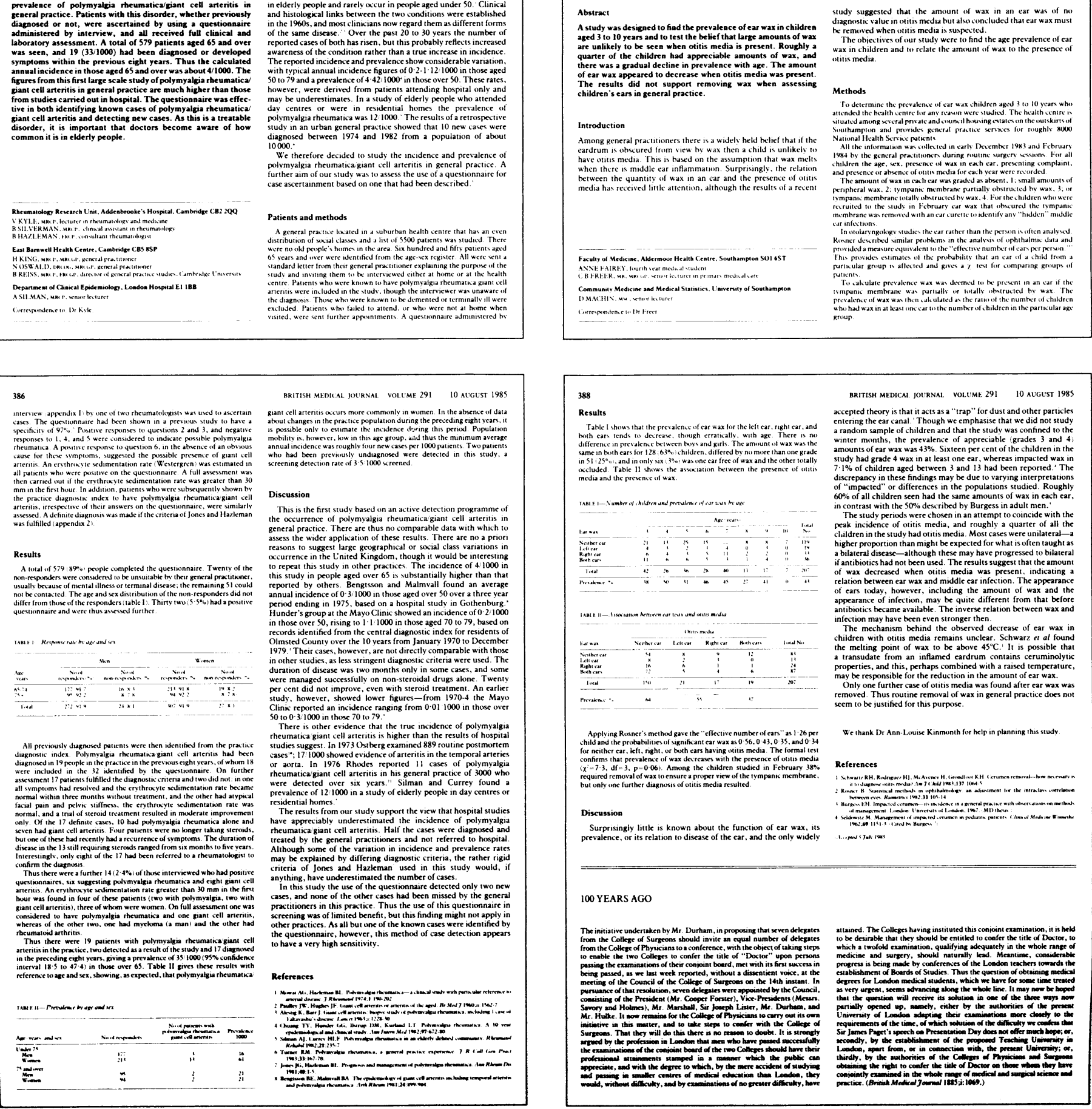